\title{
Nástin vývoje sportu v místním sdružení YMCA v Banské Bystrici v meziválečném období
}

\section{The outline of sports evolution of local union YMCA Banská Bystrica during interwar period}

\author{
Tomáš Tlustý \\ Fakulta tělesné výchovy a sportu Univerzity Karlovy v Praze
}

\begin{abstract}
Abstrakt:
Předkládaná stat pojednává o historii jednoho pomèrně významného banskobystrického sdružení, mezi jehož členstvem dosahovaly v meziválečném období značné popularity tělesná výchova a sport. Místní sdružení YMCA v Banské Bystrici výrazným způsobem přispělo ke zpopularizování celé rady sportů, mezi kterými byly na prvních místech lehká atletika, volejbal a stolní tenis. Banskobystrická YMCA patřila již od svého založení mezi hlavní piliře tohoto sdružení na Slovensku. Byla do ní investována veliká suma peněz, která byla utracena nejen během výstavby její budovy, ale také při budování sportovního zázemí. Největší popularity mezi členstvem dosahovala zřejmě lehká atletika, kterou YMCA pěstovala na "svém", na tuto dobu velice moderním hřišti. Značných úspěchů dosáhlo členstvo tohoto mistního sdružení také ve volejbalu. $V$ prüběhu 30. let však bohužel začaly tělesná výchova a sport $v$ banskobystrické YMCA upadat a pozvolna klesal i počet členů tohoto ve 20. letech velice populárního místního sdružení.
\end{abstract}

\begin{abstract}
:
The presented article deals with history of relatively important society in Banská Bystrica. During the interwar period physical education and sport were really popular among its members. YMCA society in Banská Bystrica played an important role in popularization of many kinds of sport among which were first of all athletics, volleyball and table tennis. YMCA in Banská Bystrica since its foundation belonged among the main local unions in the Slovakia. A great sum of money was invested into it and it was spent during the construction of its building as well as during construction of sports areas. Among its members the most popular sport was athletics, which was practiced on its modern field. Great achievements were accomplished in volleyball as well. During 1930s the physical education and sport started to be less popular and the count of members of this very popular society started to fall.
\end{abstract}

\section{Klíčová slova:}

YMCA; Banská Bystrica; tělesná výchova a sport; meziválečné období; výsledky

\section{Key words:}

YMCA; Banská Bystrica; physical education and sport; interwar period; results

Tato studie vznikla v rámci Programu rozvoje vědnich oblastí na Univerzitě Karlově č. 39 a za podpory SVV 2016-260346.

\section{Úvod}

YMCA (Young Men's Christian Association - Křest’anské sdružení mladých mužů) je nábožensky orientovaná mezinárodní organizace mládeže s velice širokým spektrem činností, která byla založená Georgem Williamsem v Londýně v roce 1844. K jejímu velkému rozvoji došlo především 
ve Spojených státech amerických, kde byla rovněž její tělovýchovná a sportovní činnost nejvíce preferovanou částí celého programu.

Po skončení první světové války došlo díky americkým sekretářům působícím na „starém kontinentu“ k další vlně šíření organizace YMCA, která si tak našla cestu do zemí střední Evropy, ve kterých dosud nepůsobila.

Počátky organizace YMCA v nově vzniklém Československu byly jakýmsi pokračováním činnosti tohoto mezinárodního sdružení v Itálii, Rusku a Francii. ${ }^{1}$ Českoslovenští legionáři, kteří bojovali v řadách spojeneckých vojsk, se především v těchto zemích seznámili s činností této organizace, která pro ně byla něčím novým a $\mathrm{v}$ armádě dosud nevídaným. ${ }^{2}$ Právě oni měli velikou zásluhu na tom, že YMCA rozš́írila své pole působení také na Československo.

V nově vzniklém Československu YMCA nejprve spolupracovala s místní armádou. Na Slovensku se zpočátku starala o vojenské domovy, kterých zde bylo v letech 1919 až 1921 zhruba dvacet. $^{3}$

V Banské Bystrici poznali místní obyvatelé organizaci YMCA a její činnost v roce 1919, kdy zde spravovala vojenský domov, o kterém se rozhodně nadalo říci, že by ležel v centru města. V letech 1922 a 1923 armáda postupně převzala objekty a zařízení organizace YMCA do vlastní správy. ${ }^{4}$ přes výchozí nepř́íznivou polohu si ale nakonec YMCA našla cestu mezi civilní obyvatelstvo.

Již od počátku své existence patřila banskobystrická YMCA společně s bratislavskou a lučeneckou k hlavním pilír̆umm tohoto sdružení na Slovensku. V souvislosti se vznikem místního sdružení YMCA v Banské Bystrici je pak nejčastěji uváděno datum 18. června 1921, kdy zde proběhla ustavující schůze. Předsedou výkonného výboru se stal starosta města - Július Česák.

Rozsah činnosti místního sdružení neustále rostl. Pro potřeby členů tak bylo nutné získat nové a vyhovující prostory. Dne 24. záríi 1923 se o šesté hodině večerní uskutečnila prostorech banskobystrické Tatrabanky schůze, na které přípravný výbor projednával výběr stavitele, finanční plán, ustanovil stavební výbor a vyřešil poslední detaily. Okresní úřad pak dne 4. prosince 1923 stavbu povolil a zaevidoval pod číslem 11.362/923. Roku 1924 se podařilo místnímu sdružení zabezpečit finance pro stavbu budovy, jejíž výstavba ještě před koncem roku započala.

Na žádost organizace YMCA udělilo Ministerstvo sociálních věcí po poradě s Ministerstvem veřejných prací a Ministerstvem financí dne 9. října 1924 sdružení YMCA finanční podporu, která byla ve formě převzetí záruk za hypoteční úvěr, který organizaci YMCA poskytla Zemská banka v Praze.

Stát tedy neposkytl skutečnou finanční podporu, ale spíše záruku. Pokud by tedy YMCA nebyla schopná splácet jistinu a úroky, převzal by od ní stát tuto povinnost. Záruka se týkala $70 \%$ nákladů (651 000 Kčs). Úročení hypotečního úvěru činilo 6 \% částky ročně. ${ }^{5}$

K dokončení budovy místního sdružení došlo v roce $1925 .{ }^{6}$ Mezi roky 1923 a 1929 byla do jejího vybudování a zařízení investována částka lehce přesahující 2,3 miliony korun. Finanční pomoc z Ameriky přitom mírně přesáhla částku 750 tisíc korun.?

Dva roky od schůze př́pravného výboru pro výstavbu budovy, se stavba tohoto dvoupodlažního objektu blížila svému cíli. Dne 18. záŕí 1925 vydal okresní úřad v Banské Bystrici kolaudační list, ve kterém stálo:

1 Vojenský historický archiv, Fond Ministerstvo národní obrany - presidium, roč. 1918-1923, Karton 28 , č.j. 4584, Odpověd’ předsedy vlády, ministra financi a ministra národní obrany na interpelaci poslance Böhra a druhů o marnotratném přikazování peněz YMCE.

2 Vojenský historický archiv, Fond Ministerstvo národní obrany - presidium, roč. 1918-1923, Karton 28, č.j. 4605, Policejní ředitelství Zemské správě politické v Brně dne 17. března 1921.

3 Perútka, J. (1980). Dějiny tělesnej výchovy a športu na Slovensku. Bratislava: Šport, s. 74-75.

4 Vojenský historický archiv, Fond Ministerstvo národní obrany - presidium, roč. 1918-1923, Karton 28, č.j. 5507, Cirkulární výnos č. V. ze dne 11. února 1922.

5 Sedliačik, I. (2004). Od začiatku po začiatok (Činnost' YMCA Banská Bystrica v rokoch 1919-1999). Banská Bystrica: YMCA, s. 4-5.

6 Národní archiv, Fond YMCA, Č. kartonu 7, Sign. 23, Repairs, equipment and temporary quarters.

7 Národní archiv, Fond YMCA, Č. kartonu 2, Sign. 6, Table of building expenses (local Y in ČSR 1923-1929). 
„Správe „YMCA“ v Banskej Bystrici na vystavenú budovu povolenie $k$ obývaniu s platnostou od 18. sept. b.r. udelujem. Nová budova obdrží poradové č. „Národná ulica“ č. 12."

Budova (viz obrázek 1.), ve které bylo celkem 78 místností, začala od této doby sloužit jako základna pro nejrůznější aktivity místního sdružení YMCA v Banské Bystrici. ${ }^{8}$

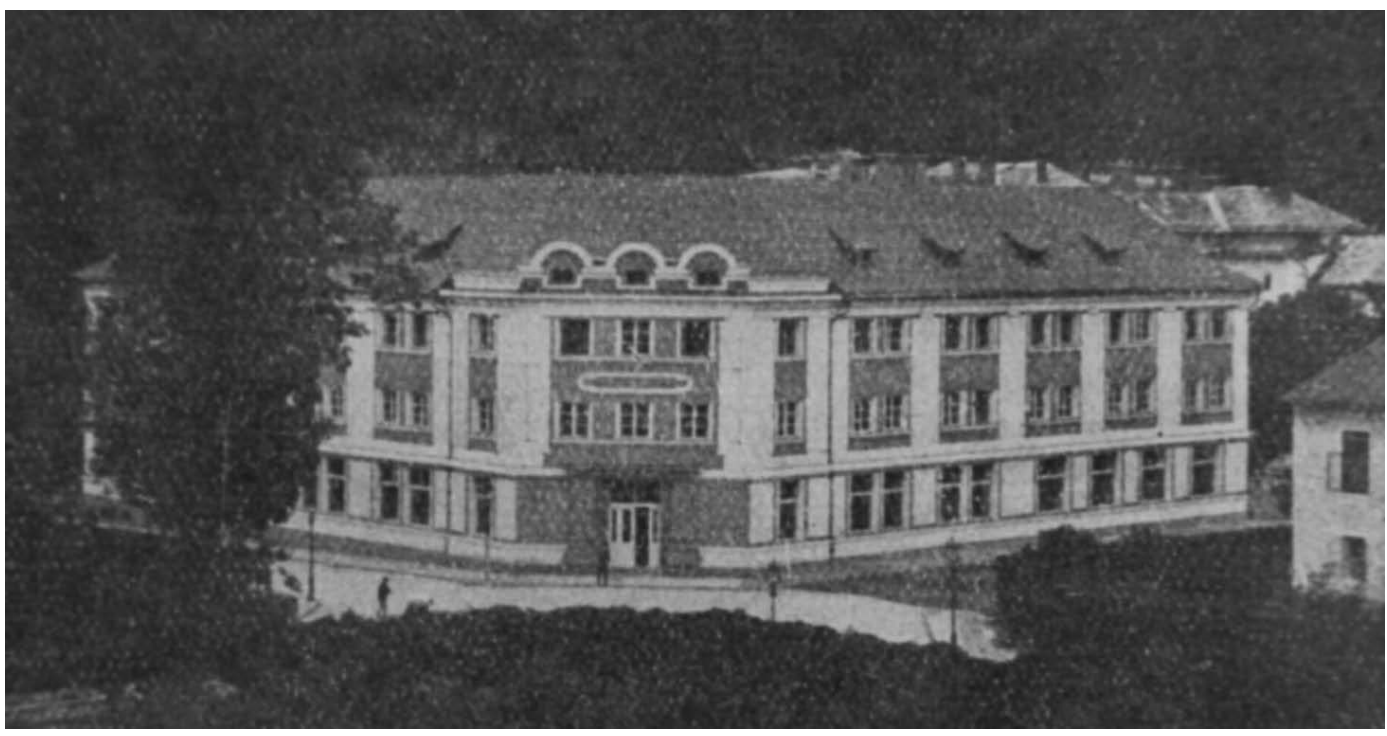

Obrázek 1. Budova místního sdružení YMCA v Banské Bystrici.

\section{Počátky tělesné výchovy a sportu v místním sdružení YMCA v Banské Bystrici}

První písemná zmínka o tělovýchovných aktivitách YMCA v Banské Bystrici pochází z června 1920, kdy místní sdružení zaslalo banskobystrické městské radě list, ve kterém ji žádalo o zřízení hřiště ve středu města.

Město se tehdy snažilo vyjít organizaci YMCA vstříc. Tehdejší starosta nabídl sdružení YMCA válkou značně poničené hřiště v Městském parku. ${ }^{9}$

„Meštanosta menovanej na Mestskom Parku sa nachodiace detské hravisko - ktoré následkom vojny bolo zničené - ukázal, s ktorým priestorom menovaná (Jessi Folson-zástupkyně ústředi YMCA) úplne spokojná bola a vyslovila sa, že na sriadit’ sa majúce toto detské hravisko prihodnejšieho priestoru ani neočakávala a prislúbila, že jestli mesto je náklonné menšie obety doniest', na tom bude pracovat', aby detské hravisko toto v Baňskej Bystrici bolo sriadené. "

YMCA ale nakonec od budování hřišš̌ v Banské Bystrici odstoupila a začala ho stavět v Bratislavě. Důvodem bylo, že Bratislava nabídla organizaci YMCA lepší možnosti spolupráce i vhodnější místo pro hřiště. ${ }^{10}$

„Po odchode z Vašeho mesta sme spravili prehliadku Bratislavy a predložili resultát našej práce pred výbor v Prahe. Výbor sa velmi potešil so zprávou v Banskej Bystrici, ale rozhodli vybudovat'

8 Sedliačik, I. (2004). Od začiatku po začiatok (Činnost' YMCA Banská Bystrica v rokoch 1919-1999). Banská Bystrica: YMCA, s. 5.

9 Tamtéž, s. 2-4.

10 Tamtéž. 
hrište v Bratislave. Pravda je to nemeckomad'arské mesto, ale chudoba je slovenská a mnohé této deti bývajú v malých izbách pod zemou kde nedojde slnce."

V roce 1922 však došlo v Banské Bystrici k obnovení myšlenky vybudování dětského hřrště. Byl to pravděpodobně první ředitel místního sdružení A. N. Wycherley, který dne 8 . března 1922 zaslal městské radě dopis s následující pasáží:

„YMCA, pokračujúc vo svojej práci pre blaho celej obce, zamýšla začat's vybudovaním hraviska pre deti. Bolo by to mestské hravisko obce Banskej Bystrici. Výbor miesteho odboru YMCA a ja, ako riaditel' práci tuná, žiadame týmto úctivo o úradné povolenie túto prácu na už vopred ustanovenom mieste v najbližšej vhodnej dobe započat'. Zdôrazňujem ešte raz, že hravisko bude mestským a k užívaniu celej obce a že YMCA vystupuje tu len ako činitel', ktorý túto akciu chce uskutočnit." "Il

Na jeho vybudování však bylo nutné sehnat dostatečné množství peněz. Ty YMCA shromáždila z různých zdrojů. Jedním z nich bylo vstupné na různé sportovní akce. Dalším byl např́íklad př́ispěvek Národní banky v Banské Bystrici:

„,Vodpovedi na Váš ct. List z 3. aprila b.r. upovedomujeme Vás úctive, že riaditel’stvo nášho ústavu odhlasovalo na postavenie detského ihrišta v Banskej Bystrici 5.000 Kč, ktorý obnos si p. Wycherley osobne vyzdvihol."

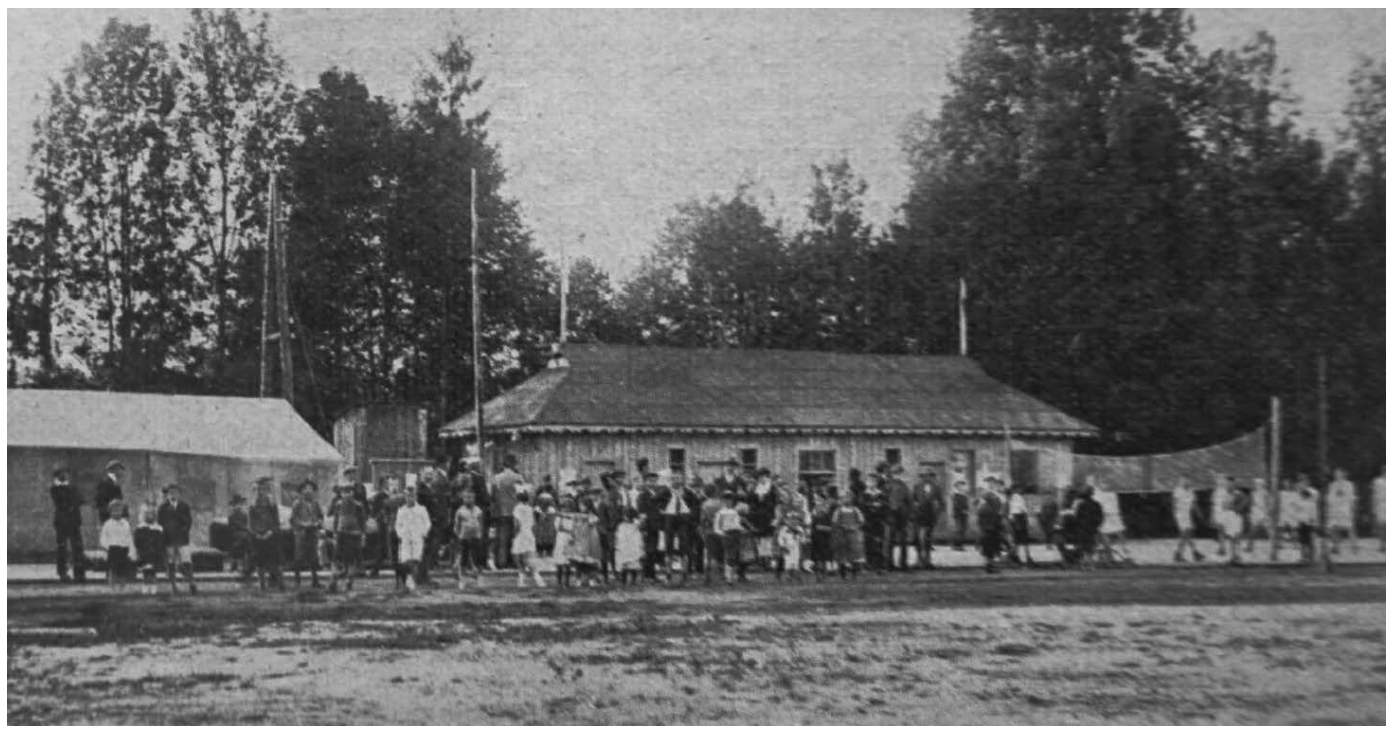

Obrázek 2. Pohled na hřiště YMCA v Banské Bystrici.

Hřiště v Banské Bystrici tak nakonec přece jen vybudováno bylo. Oficiálně bylo otevřeno dne 25. června 1922 a stálo na pozemku „U Ryby“. Celkový náklad na jeho výstavbu činil 50000 korun československých a největší podíl na jeho financování měla místní veřejnost. Hřiště, které bylo na svou dobu velice moderní a dobře vybavené, se pak stalo základnou sportujících členů místního sdružení. ${ }^{12}$ Návštěvníci zde mohli využívat velice kvalitní atletickou dráhu, volejbalové, basketbalové, házenkářské hřiště, bradla, hrazdu či kruhy. Nezůstal opomenut ani koutek pro malé děti. ${ }^{13}$

\footnotetext{
11 Tamtéž.

12 Tamtéž.

13 YMCA (Časopis sdružení YMCA v Československu), II., 1924, č. 5-6, s. 186-187.
} 
YMCA si nové hřiště nenárokovala, ale chtěla, aby se stalo spíše „městským“, nebot’ bylo také za finanční pomoci „celého“ města vybudováno. ${ }^{14}$

Na počátku roku 1923 zde již YMCA přistupovala k práci s jednotlivými skupinami, jejichž výchova a vedení byly svěřeny do rukou staršího a spolehlivého člena. Jeho prostřednictvím bylo samozřejmě možné lépe na členy dohližet, ale také se jim lépe věnovat a snáze je vést $\mathrm{k}$ tělesné výchově a sportu. ${ }^{15}$

\section{Lehká atletika}

S otevřením nového hřiště se začala mezi členy banskobystrické YMCA čím dál tím více prosazovat lehká atletika, ve které dominovaly především běhy. V roce 1923 byla též YMCA Banská Bystrica přijata za člena ČsAAU (Československá amatérská atletická unie). ${ }^{16}$ Členstvo se tak začalo účastnit různých běžeckých akcí, jakými byly např. „,běh s poselstvím na Den Svobody“, lesní běh či výroční běh městem. ${ }^{17}$

Štafetový běh městem pořádal TO (Tělovýchovný odbor) YMCA Banská Bystrica pravidelně od roku 1923. Jeho druhého ročníku, který se konal 6. dubna 1924 na trase dlouhé 3250 metrů, se zúčastnilo celkem šestnáct závodníkủ. ${ }^{18}$ Domácí Grafik (viz obrázek 3.), který vedl téměř po celou dobu závodu, nakonec prohrál po těžkém boji o cca dva metry s vítězem z roku 1923 Veljačíkem z klubu Slavia Banská Bystrica. Hlavním závodům předcházel přespolní běh atletů mladších 15 let (800 metrů) a dorostenců (1 500 metrů). Závod nejmladší kategorie ovládl Daňčík z YMCA. Celé této akci přihlíželo zhruba 2000 diváků. ${ }^{19}$

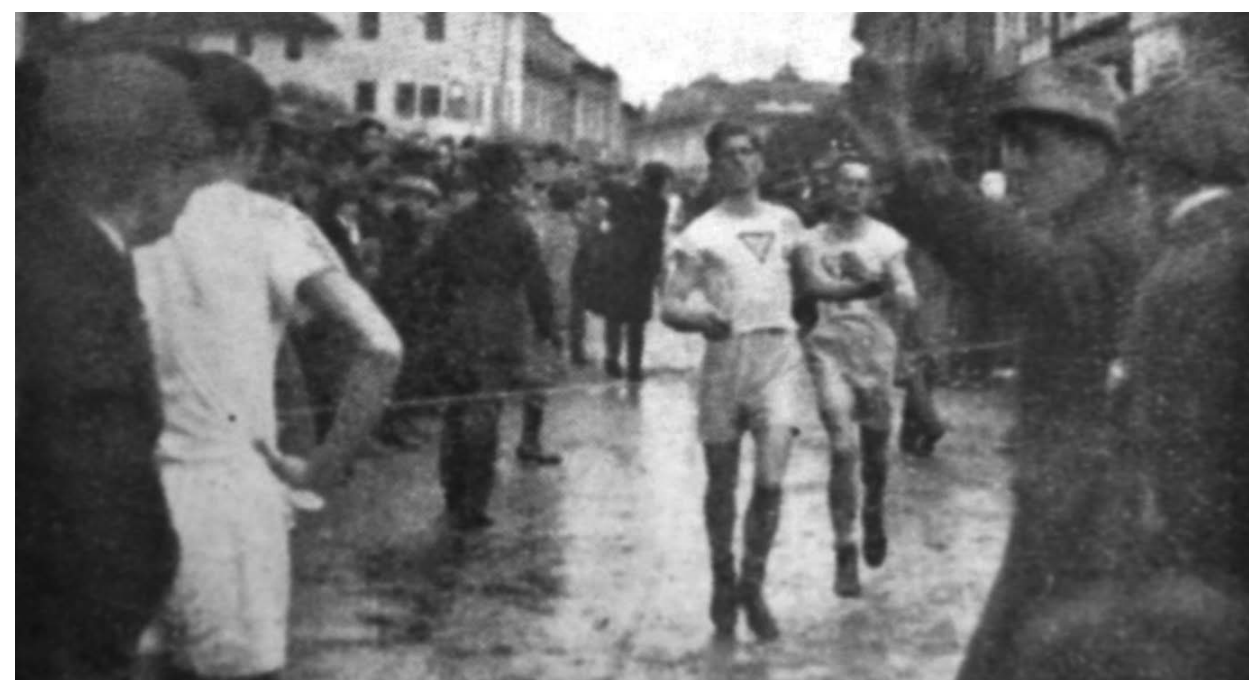

Obrázek 3. Přespolní běh v Banské Bystrici (1925). Vytrvalci YMCA Adamkovič a Grafik bojující až do cílové pásky o druhé místo.

\footnotetext{
${ }_{14}$ YMCA (Časopis sdružení YMCA v Československu), IV., 1926, č. 1, s. 20-29.

${ }^{15}$ Národní archiv, Fond YMCA, č. kartonu 4, Sign. 4, Banskobystrická YMCA v roce 1923.

${ }^{16}$ Sport, III., 1923, č. 39.

${ }^{17}$ Až do roku 1927 se stal každoroční vítěz výročního běhu městem držitelem putovní ceny prvního amerického sekretáŕe banskobystrické YMCA - A. N. Wycherleye. V roce 1927 se YMCA stala jejím definitivním držitelem, nebot' tuto cenu získala třikrát po sobě. Od roku 1928 se pak soutěžilo o cenu bratrů Velkoborských, kteři působili na Slovensku na mnoha tělovýchovných pozicích, a to např. v banskobystrické YMCA či ve Středoslovenském okrsku ČsAAU.

Chorvát, T. (2005). Banská Bystrica a šport v rokoch 1918-1938 (vplyv športu a športových spolkov na mesto a spoločnost' Banskej Bystrice v obdobi I. Československej republiky). Banská Bystrica: Hanuman, s. 26-27.

${ }_{18}$ YMCA (Časopis sdružení YMCA v Československu), II., 1924, č. 3, s. 110.

19 Sport, IV., 1924, č. 16.
} 
Dne 1. června 1924 se v Trnavě uskutečnilo přebornictví Západoslovenského okrsku ČsAAU. Závodů se zúčastnili také atleti z YMCA Banská Bystrica, kteří však př́liš úspěšní nebyli. Nejlepších výsledků z nich dosáhl Grafik, který obsadil dvě druhá místa, a to v hladkých bězích na 100 a 200 metrů. $^{20}$

Na přelomu června a července 1924 se v Banské Bystrici konaly atletické závody, na kterých si přeměřili své síly chlapci z místního TO YMCA a ŠK (Športový klub) Slavia. První jmenovaní byli také pořadateli celé akce. Kategorii chlapců (12-15 let) ovládli závodníci z YMCA, kteří porazili své soupeře v poměru $2: 7$. Stejného úspěchu chtěli jistě dosáhnout i dorostenci (15-18 let) tohoto sdružení. I těm výsledky stačily na celkové vítězství, když vyhráli poměrně výrazným bodovým rozdílem $39: 15$.

YMCA měla na těchto závodech velkou motivaci. Její výsledky se započítaly nejen jako součást závodů meziměstského pětiboje, kterého se účastnila všechna místní sdružení YMCA v Československu, ale také mezinárodního pětiboje, kterého se účastnila všechna místní sdružení YMCA v Evropě. ${ }^{21}$

V neděli 30. listopadu 1924 uspořádala YMCA Banská Bystrica k příležitosti ukončení sezony „Prvý lesní běh na Slovensku“. Této akce se zúčastnilo celkem třicet běžců, kteří soutěžili v kategoriích chlapců, dorostu a dospělých. V nejmladší kategorii se na trat' dlouhou 1500 metrů vydalo devět atletů, z nichž všichni patřili do organizace YMCA. S tratí si nejrychleji poradil Rudolf Žiljak. Těsně za ním doběhli Josef Janeček a Josef Žiljak. V patnáctičlenné konkurenci dorostenců byl na 4 kilometrové trati z běžců YMCA nejrychlejší Gregor, který obsadil celkové druhé místo. Na čtvrtém místě doběhl Haring a těsně za ním Štefko. V šestičlenném závodním poli mužủ se podařilo domácímu Adamkovičovi obsadit na trase dlouhé 7,5 kilometru třetí místo. ${ }^{22}$

Dne 5. července 1925 se zde po odehraném volejbalovém turnaji konalo lehkoatletické utkání chlapců a dorostu týmů SK (Sportovní klub) Slavia Praha a YMCA Banská Bystrica. Na úvod nastoupila obě družstva se svými vedoucími Havlem a Odvarkou před obecenstvo, pozdravila se a zástupce domácích atletů Seneš předal Pražanům čestnou vlajku. Poté již místní závodníci ukázali, že dovedou využít této ojedinělé př́ležitosti $\mathrm{k}$ přeměření svých sil s prvotřídním atletickým družstvem. Mohli pouze litovat, že podobné závody byly v Banské Bystrici výjimečné, nebot' místní YMCA takřka neměla v okolí konkurenci. Kategorii chlapců ovládli domácí závodníci v poměru $32: 22$. Družstvo SK Slavia Praha tak jistě chtělo domácím oplatit tuto porážku v kategorii dorostenců. To se jim také podařilo. Pražané zvítězili $65: 43 .^{23}$

Mohlo by se zdát, že lehká atletika byla v Banské Bystrici skutečně populární, ale opak byl pravdou. Kluby ji takřka nepěstovaly. Jedinou výjimkou byla právě místní YMCA. Tělovýchovný ředitel YMCA Lewis William Riess se však neustále snažil o její pozvednutí a doufal, že se brzy přidají i další kluby. Velmi důležitým faktorem ale bylo, že se zde lehká atletika těšila zájmu diváků. ${ }^{24}$

O pozvednutí lehké atletiky v Banské Bystrici se místní YMCA snažila také tím, že se její funkcionáři několikrát pokusili domluvit účast špičkového zahraničního atleta na místních závodech. Po dvojnásobném olympijském vítězi Charlesu „Charleyemu“ Williamu Paddockovi, který přijal pozvání československé YMCA v roce 1923, zavítal v roce 1925 do Banské Bystrice Samuel Harrison Thomson. Diváci, kteří zde viděli jeho vystoupení, měli opravdu na co vzpomínat. Tolika disciplín se zde totiž ještě žádný atlet nezúčastnil. Jím dosažené výsledky se vůbec nedaly srovnat s výkony, které byly v té době mezi členy banskobystrické YMCA běžné.

V jednotlivých soutěžích byly dosažené následující výsledky: Překážkový běh na 110 metrů ovládl Thomson (16,2 sekundy) před Barboriakem (17,3 sekundy). Thomson zvítězil i v překážkovém běhu na 200 metrů (28 sekund), kde porazil Ružinského (29,2 sekundy) a Snačka. Suverénní vítězství předvedl Thomson ve skoku vysokém (174 centimetrů), kde porazil své dva konkurenty - Seneše

\footnotetext{
20 Sport, IV., 1924, č. 24.

21 Sport, IV., 1924, č. 30.

22 Sport, IV., 1924, č. 63.

23 Sport, V., 1925, č. 29.

24 Sport, VI., 1926, č. 10, s. 11.
} 
(159 centimetrů) a Barboriaka (154 centimetrů). Ve skoku dalekém zvítězil opět Thomson ( 6,1 metru) před Barboriakem (5,3 metru) a Ružinským (5,01 metru). Roli favorita potvrdil Thomson i ve skoku o tyči (3 metry). Zde porazil tyčkaře Danka (2,8 metru) a Sekurise (2,6 metru). Ve skvělých výkonech pokračoval Thomson i ve vrhu koulí. Zde rovněž obsadil první místo $(12,23$ metru), když vrhl dál než Tůma (10,26 metru) a Jakša. Thomson rovněž hodil nejdále diskem (36,15 metru), ve kterém výrazným rozdílem porazil svého konkurenta Tůmu (30,47 metru). Tůma však vzápětí Thomsonovi své porážky oplatil, když ho přehodil oštěpem $(39,45$ metru). To byla také jediná porážka tohoto atleta (38,5 metru) na lehkoatletickém mítinku v Banské Bystrici. V ostatních závodech, kterých se již Thomson neúčastnil, bylo i tak k vidění několik pěkných výkonů. Celé závody s účastí $\mathrm{S}$. $\mathrm{H}$. Thomsona byly jistě pro místní atlety poučné, a to jak po technické, tak i po morální stránce. ${ }^{25}$

Na rozdíl od závodů, kterých se účastnil S. H. Thomson, se dokázali atleti banskobystrické YMCA prosadit na okrskovém mistrovství ve všech disciplínách s výjimkou běhu na 5 kilometrů a skoku o tyči. Členstvo sdružení YMCA, ač závodilo převážně samo proti sobě, předvedlo řadu dobrých výsledků. ${ }^{26}$

V neděli 19. dubna 1925 uspořádala YMCA Banská Bystrica štafetový běh na $5 \times 200$ metrů např́íc městem. Celá akce proběhla za pěkného počasí a slušné divácké návštěvy. Závody se konaly ve třech kategoriích - dospělí, dorostenci a chlapci. V kategorii dospělých měla YMCA ve složení Kardoš - Jakša - Barboriak - Ružinský ml. - Grafik konkurenci v banskobystrickém týmu Slavia. Ten hned na prvním úseku získal čtyřmetrový náskok, který však Jakša smazal a dokonce předal s půlmetrovým vedením. Barboriak pak prudce vyrazil, ale při předání kolíku z pravé ruky do levé mu kolík upadl, čímž bylo o vítězi závodu prakticky rozhodnuto. Ružinský na předposledním úseku předvedl snad nejlepší běh ze všech závodníků. Podařilo se mu výrazně stáhnout velkou ztrátu. Grafik se ale již nebyl schopen na první místo probojovat. YMCA tak prohrála o cca osm metrů. Druhé místo obsadila též v závodu dorostenců, ve kterém její štafeta ve složení Leneš - Gregor - Mojžíš - Matrtaj - Záhor prohrála rovněž s atlety místní Slavia. Na těchto závodech byly týmy velice vyrovnané, a tak rozhodovalo především předávání a přebírání kolíku. ${ }^{27}$

Místní atletická skupina se v roce 1925 rovněž představila v Praze. ${ }^{28} \mathrm{~V}$ červnu 1925 totiž uspořádala pražská Slavia druhý výroční pětiboj šestičlenných atletických týmů do 15 let. Družstvo YMCA Banská Bystrica vedl sekretár Velkoborský. V konkurenci 54 atletů se YMCA prezentovala velice dobře a byla možná nejlepším slovenským týmem. $Z$ jejích řad vynikal především Kárpáty, který skončil na třetím místě v hladkém běhu na 100 metrů a na děleném prvním místě ve skoku dalekém. Kárpáty byl rovněž členem štafety na $6 \times 100$ metrů, která zde obsadila druhé místo. Společně s ním běželi Ivanič, Kožehuba, Machačka, Rázga a Jánoš. Dalšími úspěšnými atlety reprezentujícími banskobystrickou YMCA byli Machačka, který zaznamenal druhý nejlepší výsledek v hodu kriketovým míčkem, a Jánoš, který obsadil třetí místo ve skoku dalekém. Tyto výkony stačily atletům YMCA na zisk celkového druhého místa $\mathrm{v}$ pořadí týmů. $\mathrm{V}$ konkurenci čtyř klubů a devíti týmů si nejlépe vedla Slavia I, která získala 28,5 bodu. YMCA na ni ztratila 13 bodů. ${ }^{29}$

Dne 28. záŕí 1925 uspořádala YMCA Olomouc na své nově vybudované závodní dráze lehkoatletické přebornictví YMCA v Československu. Do Olomouce se sjelo více než 150 atletů z jedenácti měst. Ti byli rozděleni do třech kategorií (hoši 12-15 let, dorost 15-18 let a závodníci starší 18 let) a soutěžili celkem ve 24 disciplínách. $K$ vidění byly poměrně pěkné výkony.

V nejmladší kategorii žáků o sobě dali z Banské Bystrice nejvíce vědět Papp, který obsadil třetí místo v běhu na 75 metrů a vyhrál soutěž ve skoku dalekém s rozběhem, a Gašpar, který vybojoval druhé místo $\mathrm{v}$ hodu baseballovým míčkem. Banskobystričtí atleti si taktéž doběhli pro druhé místo v rozestavném běhu na $4 \times 100$ metrů, když nestačili pouze na vítěznou Olomouc. Na třetím místě

\footnotetext{
${ }^{25}$ Sport, V., 1925, č. 24.

${ }^{26}$ Sport, V., 1925, č. 22.

27 Sport, V., 1925, č. 16.

${ }^{28}$ Almanach sportu na rok 1926, roč. 1926, s. 24-26.

${ }^{29}$ Sport, V., 1925, č. 22.
} 
se umístila kombinovaná štafeta Brna a Banské Bystrice. Větších úspěchů dosáhli atleti z Banské Bystrice v kategorii dorostenců. V hladkém běhu na 100 metrů si Seneš doběhl pro třetí místo. I. Vagač obsadil první místo v běhu na 110 metrů překážek. Vítězství pro svůj tým získal též Záhor, který vyhrál ve vrhu koulí. Jeho týmový kolega Bíreš skončil na třetím místě. Dorostenci závodili též v rozestavném běhu na $4 \times 200$ metrů. Banskobystrická štafeta však nestačila na Hradec Králové a obsadila celkové druhé místo před třetím Libercem. Jediným větším úspěchem banskobystrické atletiky v kategorii dospělých bylo třetí místo Tůmy ve vrhu koulí.

Lehkoatletickým mistrem československé YMCA se pro rok 1925 stalo družstvo YMCA Hradec Králové, které získalo 60,5 bodu. Druhé místo vybojovali se ziskem 40 bodů atleti Brna. Ti byli pronásledováni Libereckými, kteří si v soutěžích připsali 34,5 bodu. Na následujících místech se umístila Banská Bystrica (29 bodů), Znojmo (16 bodů), České Budějovice (13 bodů), Olomouc (12 bodů), Kladno a Bratislava (oba 6 bodů) a Kroměříž (1 bod). ${ }^{30}$ Vítězství Hradce Králové bylo velkým překvapením. Všeobecně se totiž předpokládalo, že zvítězí někdo z dvojice Banská Bystrica - Liberec. ${ }^{31}$

Dne 30. listopadu 1925 se členové YMCA zúčastnili přespolního a lesního běhu v Banské Bystrici. Závodilo se ve třech kategoriích. Nejmladší běžci soutěžili na trase dlouhé 1 kilometr. Dorostenci běželi 4 kilometry a nejstarší a nejzkušenější běžce čekala trasa dlouhá 8 kilometrů. S osmikilometrovou tratí si nejlépe poradil Odvárka, kterého stíhal Ružinský st. ${ }^{32}$

Na lehkoatletickém přebornictví Československa roku 1926 v Přerově pak nemohli atleti z YMCA Banská Bystrica chybět. Na této velké akci se utkalo více jak 12 klubů z celé republiky. Nejvýraznějších výsledků z banskobystrické YMCA dosáhli následující atleti: Vagač obsadil v běhu na 400 metrů druhé místo, Krno vybojoval druhé místo na dvojnásobné trati a druhé místo rovněž obsadil Durný ve skoku o tyči. Po sečtení bodů, které získali jednotliví atleti ve svých disciplínách, bylo nepochybné, že nejlepší atleti na těchto závodech jsou členové SK Přerov (41,5 bodu). YMCA Banská Bystrica skončila s 12 body na čtvrtém místě. ${ }^{33}$

O poměrně vysoké úrovni atletů YMCA v Banské Bystrici však svědčí fakt, že se v roce 1926 stali její atleti okrskovými mistry opět $\mathrm{v}$ mnoha disciplínách. Seneš se stal okrskovým mistrem v běhu na 100 a 200 metrů. První místo rovněž vybojoval ve skoku do dálky. Jeho týmový kolega Valint ovládl skok vysoký, vrh koulí a hod diskem. YMCA Banská Bystrica se tak poměrně přesvědčivě stala okrskovým atletickým přeborníkem v kategorii týmů. ${ }^{34}$

TO YMCA v Banské Bystrici uspořádal 3. dubna 1927 za pěkného počasí V. výroční běh městem o putovní cenu prvního amerického sekretáře A. N. Wycherleye. Tyto závody, které se těšily uspokojivé účasti diváků, byly vypsány pro tři kategorie. O putovní cenu závodila na trase dlouhé 3,2 kilometru čtyřčlenná družstva dospělých běžcủ. Prvním závodníkem, který protnul cílovou čáru, byl Záhorák. S větším odstupem za ním doběhl do cíle Haring. Oba tito závodníci reprezentovali domácí YMCA. V kategorii dorostenců se soutěžilo na trase dlouhé 1600 metrů. Zde se na prvních dvou místech umístili rovněž domácí běžci. Vítězství vybojoval Žiljak, který jen těsně porazil Kurtu. V kategorii chlapců se na prvních třech místech opět umístili domácí závodníci. Trat' dlouhou 600 metrů zdolal nejrychleji Kučera. Za ním doběhli Selecký a Dobrota. Všichni tři závodníci, kterým se podařilo zvítězit ve svých kategoriích, si navíc zlepšili časy z minulého roku. ${ }^{35}$

Týmy YMCA Banská Bystrica a ŠK Žilina se utkaly dne 16. června 1927 v rámci přebornictví Středoslovenského okrsku ČsAAU. Pouze pětičlenné, ale výkonnostně vyrovnané družstvo ŠK Žilina

\footnotetext{
${ }^{30}$ Pramen nejprve uvádí, že se do Olomouce sjeli atleti z jedenácti měst, ale ve výsledkové listině jich pak udává pouze deset.

31 Táborový zpravodaj YMCA, II., 1925, č. 2-3, s. 13.

32 Táborový zpravodaj YMCA, II., 1925, č. 2-3, s. 10-11.

33 Sport, VI., 1926, č. 39.

34 Almanach sportu na rok 1927, roč. 1927, s. 34-35.

35 Sport, VII., 1927, č. 15.
} 
dosáhlo na hřišti hostí zaslouženého vítězství v poměru $67: 59$. Ve prospěch početnějšího týmu YMCA navíc hrála značnou roli vysoké teplota. ${ }^{36}$

Atleti z YMCA Banská Bystrica však i přes tuto porážku patřili ve Středoslovenském okrsku ČsAAU k nejlepším. Z jejích řad nejvíce vynikali sprinteři Matrtaj, ${ }^{37}$ Jáno $^{38}$ a Kárpáty. Na hladkých tratích 400 a 800 metrů pak vynikal Krno.$^{39}$ Nejlepší časy na 1500 metrů předváděli Záhorák, Rudolf Žiljak a Kurta. V běhu na 5 kilometrů dominoval Gabriel Haring. Nejvýše naopak skákal Durný. Tento atlet byl nejlepší též ve skoku o tyči. Ve vrhu koulí dosáhl nejlepšího výsledku z YMCA Banská Bystrica Záhor, stejně jako v hodu diskem a oštěpem. ${ }^{40}$

Neděle 1. dubna 1928 zde byla ve znamení VI. výročního běhu přes město o putovní cenu bratrů Velkoborských, čímž byla zahájena atletická sezona $v$ Banské Bystrici. Na tyto závody, které pořádala místní YMCA, se přihlásilo 34 závodníků z Lučence, Žiliny a Banské Bystrice. Putovní cenu pro rok 1928 získalo domácí družstvo. Kromě toho obdržel Gabriel Haring cenu předsedy Středoslovenského atletického okrsku - lesmistra Zikmunda za dosažení nejlepšího času. Průběhu závodů přihlíželo poměrně dost diváků. ${ }^{41}$

Koncem ř́ijna 1928 se v Košicích konal V. mezinárodní maraton o přebor Slovenska, který uspořádal Východoslovenský - Podkarpatoruský okrsek ČsAAU. Závod probíhal na trati Gajdové kúpele, košická hlavní třída, Barca, Haniska, Šeňa a zpět s cílem na hřišti Slavia. Na trati se představilo celkem 45 závodníků, kteří pocházeli napřr. z Prahy, Budapešti, Vídně, Berlína, Košic či Užhorodu. ${ }^{42}$ Do cíle jich však doběhlo pouze 24. Z YMCA Banská Bystrica se nejlépe umístil Gregora, který $\mathrm{v}$ těžké konkurenci obsadil šestnácté místo. ${ }^{43}$

V roce 1929 se podařilo běžcům z YMCA Banská Bystrica obhájit své prvenství z výročního běhu přes město o putovní cenu bratrů Velkoborských. Závodů se zúčastnilo pět družstev - YMCA I, YMCA II, Slavia, 26. pěší pluk a jeho kulometná rota. ${ }^{44}$

V polovině třicátých let však začala lehká atletika v Banské Bystrici upadat. A přitom se ještě v roce 1932 o tomto městě dalo ř́ici, že je to centrum slovenské atletiky. Rovněž atletická dráha YMCA Banská Bystrica patřila v této době mezi nejživější na Slovensku. Místní akce většinou organizovali sekretáři YMCA Zelenka a Velkoborský. Po jejich odchodu z Banské Bystrice však pozvolna začaly stadiony zarůstat trávou. Pozastavení činnosti zde však vykazovaly i další kluby, jako např́íklad dříve poměrně aktivní Slavia Banská Bystrica. Tento se rok od roku 1933 do roku 1938 př́liš neměnil. ${ }^{45}$

\section{Těžká atletika}

Kromě lehké atletiky se v banskobystrické YMCA pěstovala také atletika těžká. V roce 1923 zde vznikl těžkoatletický klub TAC (Těžkoatletický club) Ursus (viz obrázek 4.). Ten byl sice zaměřený především na zápas, ale své místo si v něm našel také box. ${ }^{46}$

\footnotetext{
${ }^{36}$ Sport, VII., 1927, č. 26.

${ }^{37}$ Matrtaj předvedl svou skvělou formu také na Světových hrách YMCA v Kodani v roce 1927.

The Y.M.C.A. Games (Official Report of the First International Y.M.C.A. Athletic Championships: Copenhagen, Denmark, July 10-17, 1927). (1927). Ženeva: World's Alliance of Young Men's Christian Associations, s. 30.

${ }^{38}$ Dorostenec Jánoš běhal v této době skvěle i překážkový běh na 200 metrů.

${ }^{39}$ Tento atlet rovněž neudělal ostudu na Světových hrách YMCA v Kodani.

${ }^{40}$ Sport, VIII., 1928, č. 1.

${ }^{41}$ Sport, VIII., 1928, č. 16.

${ }^{42}$ Sport, VIII., 1928, č. 44.

${ }^{43}$ STAR, roč. 1928, č. 44.

${ }^{44}$ Chorvát, T. (2005). Banská Bystrica a šport v rokoch 1918-1938 (vplyv športu a športových spolkov na mesto a spoločnost' Banskej Bystrice v obdobi I. Československej republiky). Banská Bystrica: Hanuman, s. $26-27$.

45 STAR, roč. 1936, č. 13.

${ }^{46}$ Archiv YMCA v Bratislavě, YMCA na Slovensku, Povereníctvu pre veci vnútorné, odbor IV ze dne 16. května 1945.
} 
Těžká atletika v místním sdružení však nikdy nedosáhla popularity atletiky lehké a také zmínky o činnosti klubu TAC Ursus se v novinových článcích př́liš nevyskytovaly. Je tudíž pravděpodobné, že se těžcí atleti banskobystrické YMCA závodů př́liš neúčastnili nebo že tento klub velice záhy zanikl.

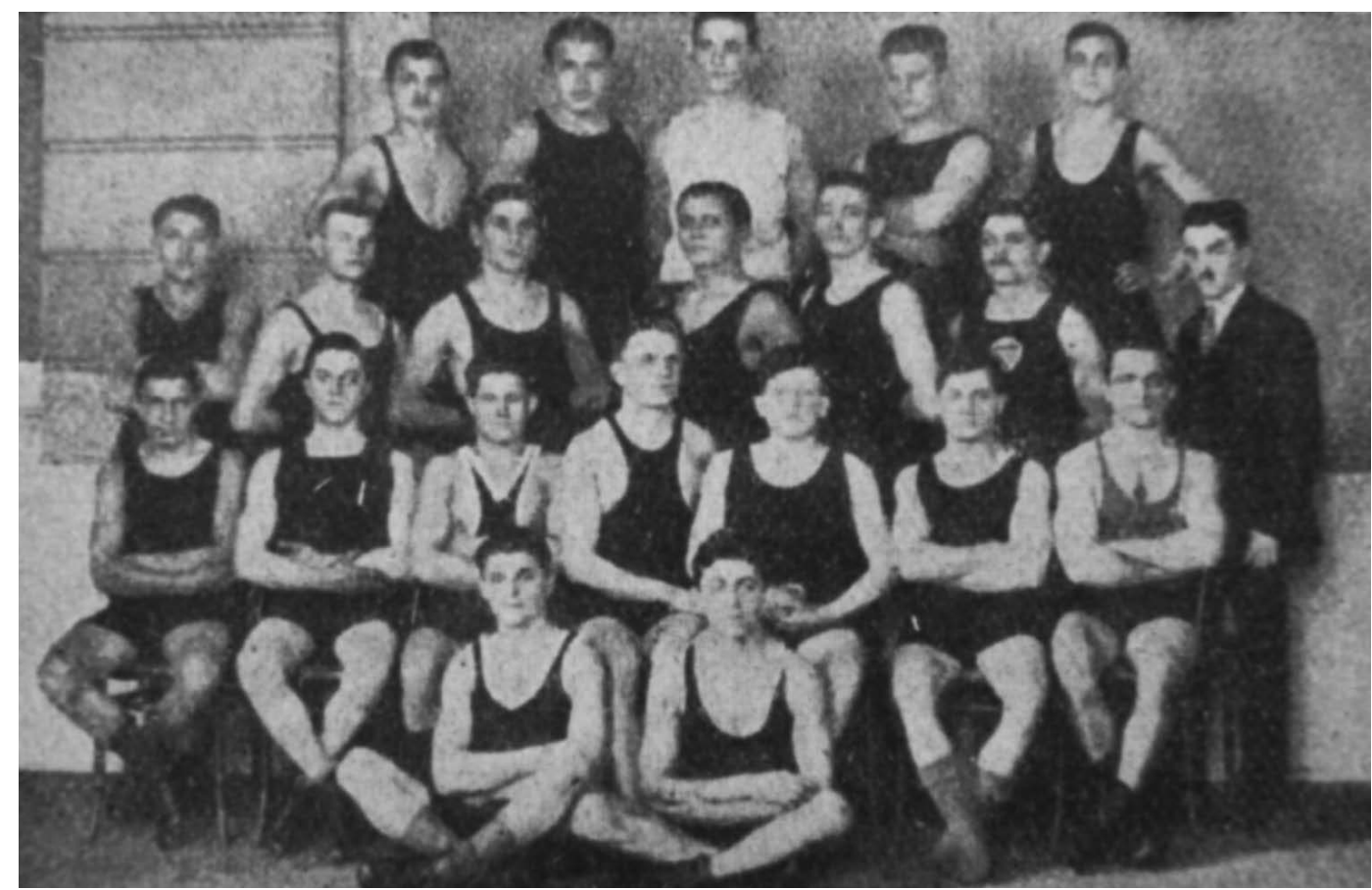

Obrázek 4. Těžkoatletický klub banskobystrické YMCA - TAC Ursus.

\section{Basketbal a volejbal}

Stejně jako v mnoha dalších místních sdruženích v Československu, tak i v banskobystrické YMCA byly značně populární „,americké hry“ - basketbal a volejbal. Největším problémem pro jejich pěstování ale bylo, že v Banské Bystrici nebyly na počátku 20. let vybudované tělocvičny. Byla zde pouze jedna, a to uprostřed města. Místní sdružení se tak o ni samozřejmě muselo dělit se školami, které zde obsadily většinu hodin. V banskobystrické YMCA tak mohli jen doufat, že pokud se jim podaří postavit vlastní tělocvičnu, stanou se tyto hry jejich „zlatým sportovním hřebem“ zimní sezony. ${ }^{47}$

V roce 1923 začala YMCA v Československu organizovat závody v hodu do koše, na které v následujícím roce navázala. Také tyto akce pomáhaly vzbudit zájem o basketbal. Jednotlivé týmy vznikající v místních sdruženích YMCA spolu brzy začaly svádět zápasy o primát $\mathrm{v}$ této hře. Vyvrcholením pak bylo první „mistrovství her“ v Olomouci, z něhož si titul mistra československé YMCA v basketbalu pro rok 1924 odvezla právě YMCA Banská Bystrica. ${ }^{48}$

$\mathrm{V}$ tomto roce se YMCA Banská Bystrica stala též poprvé basketbalovým mistrem Slovenska. Tento titul se jí podařilo vybojovat také v následujících dvou sezonách. ${ }^{49}$

Banská Bystrica ale především patřila mezi města, kde se hrál výborný volejbal, který svou úrovní přerostl nejen krajský, ale též celoslovenský rámec. Mezi průkopníky volejbalu na Slovensku patřili

${ }^{47}$ YMCA (Časopis sdružení YMCA v Československu), II., 1924, č. 5-6, s. 186-187.

${ }^{48}$ Perútka, J. et al. (1967). Športy na Slovensku v rokoch 1945-1965. Bratislava: Šport, s. 43.

${ }^{49}$ Chorvát, T. (2005). Banská Bystrica a šport v rokoch 1918-1938 (vplyv športu a športových spolkov na mesto a spoločnost' Banskej Bystrice v obdobi I. Československej republiky). Banská Bystrica: Hanuman, s. $26-27$. 
Durný, Caban, Žiljak, Konôpka či Selecký. ${ }^{50}$ YMCA často pořádala v Banské Bystrici propagační volejbalové turnaje, jichž se účastnila místní družstva, spolky či školy. ${ }^{51} \mathrm{~V}$ této době již v českých zemích pěstovalo volejbal nemálo klubů. Oproti tomu na Slovensku byl alespoň zpočátku volejbal záležitostí především členstva organizace YMCA.

Již v roce 1924 se banskobystrická YMCA utkala v rámci volejbalového mistrovství Československa s pozdějším vítězem - mužstvem Strakovy akademie Praha, které ji porazilo $2: 0$ na sety. $^{52}$

V neděli 5. července 1925 se na kvalitně upraveném hřišti YMCA v Banské Bystrici uskutečnil volejbalový turnaj o mistra Slovenska, ${ }^{53}$ který byl zároveň vylučovacím turnajem pro blížící se mistrovství YMCA v Československu. Turnaj však byl pouze doplňkovou složkou již dřive uvedených lehkoatletických závodů.

Do volejbalových bojů nastoupila čtyři družstva YMCA - Akademická YMCA Bratislava, YMCA Bratislava a dva týmy postavila pořádající banskobystrická YMCA. Po dopoledních bojích se do odpoledního finálového zápasu kvalifikovala dvě nejsilnější družstva - YMCA Bratislava a YMCA Banská Bystrica I. Po tuhém boji vybojovala vítězství v poměru $2: 1$ na sety YMCA Banská Bystrica I, která se tak stala prvním mistrem Slovenska ve volejbalu. Vítězové turnaje po většinu svých zápasů jasně dominovali, což dokazuje i jejich celkový bodový poměr $128: 51$. Volejbalové zápasy zde se zájmem sledovalo poměrně dost diváků. ${ }^{54}$

V pondělí 28. záŕí 1925 bylo v Olomouci sehráno mistrovství YMCA ve volejbalu a basketbalu mezi mistry Čech, Moravy a Slovenska. ${ }^{55}$ Volejbalovou část ovládlo družstvo z Prahy před Olomoucí a Banskou Bystricí. V basketbalu zvítězila Banská Bystrica před Olomoucí a Hradcem Králové. Vítězné týmy získaly od ústředí YMCA plakety. ${ }^{56}$

Stejně jako v předchozí sezoně se i v roce 1926 konalo na hřišti místního sdružení YMCA v Banské Bystrici volejbalové mistrovství Slovenska. Mistrovský titul vybojovali opět volejbalisté YMCA Banská Bystrica. V této době již místní YMCA disponovala několika volejbalovými a basketbalovými týmy, jejichž názvy byly např. Mohykáni či Viktória. Své týmy měli též správci budovy a úředníci tohoto místního sdružení. V roce 1928 se místnímu týmu navíc podařilo stát se volejbalovým mistrem československé YMCA (viz obrázek 5.).

${ }^{50}$ Perútka, J. et al. (1967). Športy na Slovensku v rokoch 1945-1965. Bratislava: Šport, s. 354.

${ }^{51}$ Chorvát, T. (2005). Banská Bystrica a šport v rokoch 1918-1938 (vplyv športu a športových spolkov na mesto a spoločnost' Banskej Bystrice v obdobi I. Československej republiky). Banská Bystrica: Hanuman, s. $27-28$.

52 Šarochová, K. (2013) YMCA a Vysokoškolský sport jako pri̊kopníci volejbalu v Českých zemích. (Diplomová práce). Praha: Univerzita Karlova v Praze, s. 43.

${ }^{53}$ Zde se dostupné prameny liší. Dobový tisk uvádí, že se již tento rok konalo volejbalové mistrovství Slovenska. Naopak Perútka, J. (1982). Malá encyklopédia telesnej výchovy a športu. Bratislava: Šport, s. 602 uvádí, že první volejbalové mistrovství Slovenska se uskutečnilo až v roce 1928.

54 Sport, V., 1925, č. 29.

55 Táborový zpravodaj YMCA, II., 1925, č. 2-3, s. 13.

${ }^{56}$ Sport, V., 1925, č. 39. 


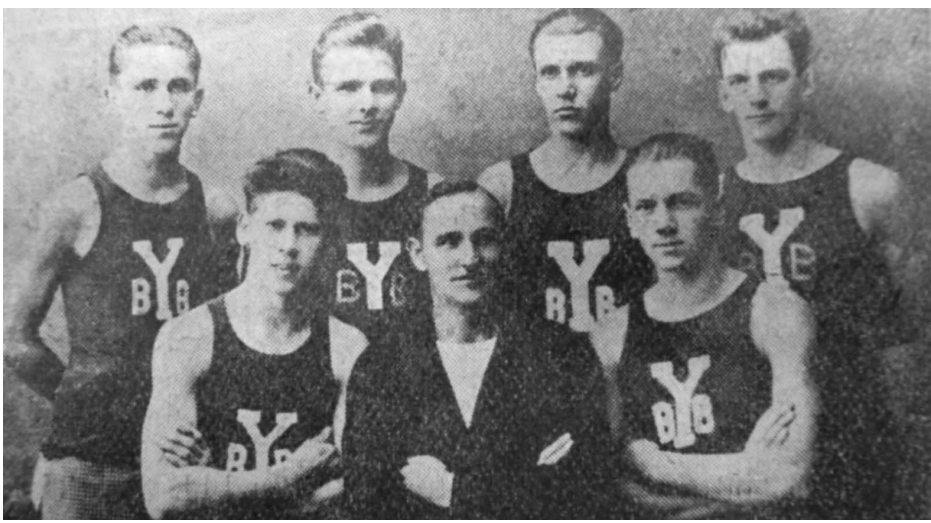

Obrázek 5. Družstvo YMCA Banská Bystrica, které se stalo volejbalovým mistrem československé YMCA pro rok 1928. Stojící zleva: Jánoš, Bíreš (kapitán), Sobota, Kožehuba. Sedící zleva: Durný, Fikejž, Selecný.

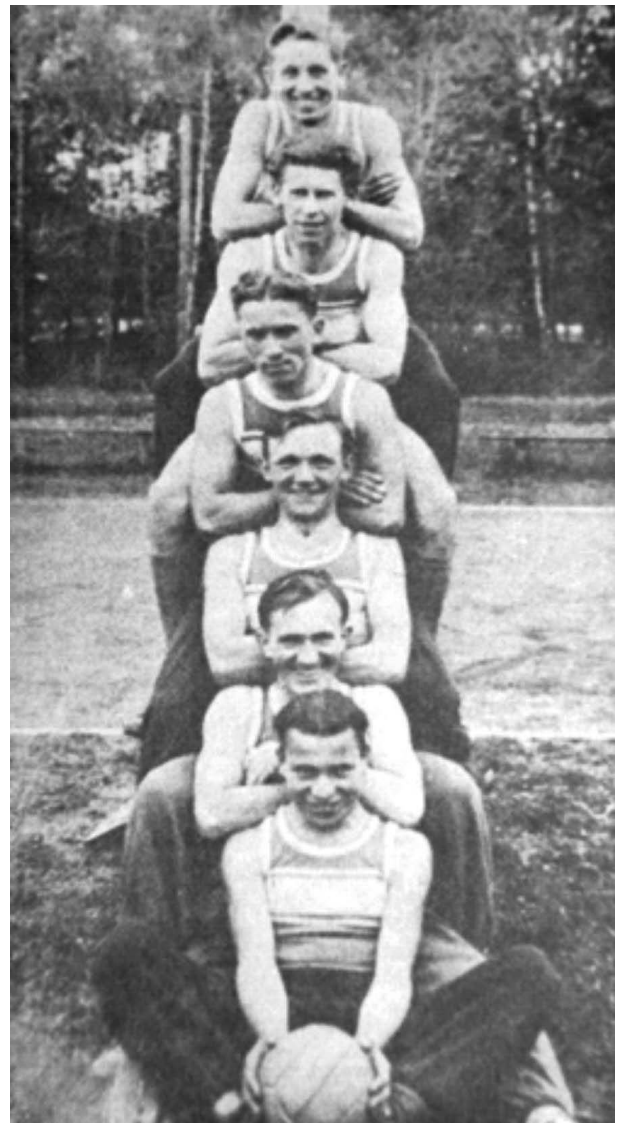

Obrázek 6. Mistři Slovenska ve volejbalu pro rok 1932-YMCA Banská Bystrica.
V pořadí VII. mistrovství republiky ve volejbale se v roce 1930 poprvé konalo na území dnešního Slovenska, a to v Tatranské Lomnici ve dnech 16. a 17. srpna. Na této sportovní akci se mělo utkat devět nejlepších československých týmů - tři z Čech, Moravy a Slovenska. Z Čech však prijel pouze mistr - Strakova akademie Praha. Ze Slovenska se na tuto akci probojovali mj. volejbalisté YMCA Banská Bystrica. Těm se však př́liš nedařilo.

Nejprve podlehli pražské Strakově akademii $2: 0$. Následně porazili Sokol Přerov $2: 1$ a začali pomýšlet na dobré umístění. Plány banskobystrické YMCA však zhatil tým ČSS (Česká sportovní společnost) Olomouc, kterému podlehla opět $2: 0$. Po tomto výsledku již v žádném př́padě nemohla pomýšlet na celkový triumf. Neprobojovala se ani mezi nejlepší tři týmy. Vítězem se stali volejbalisté Strakovy akademie Praha. $^{57}$

Volejbalové mistrovství Československa pro rok 1931 se konalo o víkendu 19. a 20. záríi v Pardubicích. Volejbalisté a volejbalistky zde na šesti travnatých kurtech bojovali o ceny, které do turnaje věnovali František Smotlacha a firma Fotoservice. ${ }^{58}$

Banskobystrické YMCA se opět nedařilo, nebot' utrpěla na úvod porážku od Sokola Brno I, který ji přehrál rozdílem tř́́dy v poměru $2: 0$. Ve druhém zápase se YMCA utkala s týmem STAR Praha, na který rovněž nestačila a prohrála $2: 0$. Ve třetím zápase se však hráčům YMCA podařilo zvítězit v poměru $2: 1$.

57 Almanach sportu a tělesné výchovy na rok 1930, roč. 1930, s. 136.

58 STAR, roč. 1931, č. 39. 
Do finálové skupiny se ale banskobystrická YMCA neprobojovala. Své prvenství z minulého roku potvrdili hráči Strakovy akademie Praha..$^{59}$

V roce 1932 opět organizovala YMCA Banská Bystrica mistrovství Slovenska ve volejbalu. Na domácím hřišti se jejím volejbalistům podařilo získat další mistrovský titul (viz obrázek 6.). ${ }^{60}$ Vytouženého úspěchu na celostátní úrovni však opět nedosáhli.

V roce 1933 se pak YMCA Banská Bystrica umístila v rámci slovenského volejbalového mistrovství na druhém místě za týmem YMCA Bratislava a do pozice nejlepšího slovenského volejbalového týmu se jí již nikdy nepodařilo vrátit. ${ }^{61}$

\section{Playgroundball}

V banskobystrické YMCA se postupem času utvořil také silný playgroundballový ${ }^{62}$ tým, který v konkurenci československých sdružení YMCA vybojoval celkem tři tituly. ${ }^{63}$

Tato hra však nikdy v Československu př́lišné popularity nedosáhla. Nevzniklo zde ani velké množství týmů. Členstvo YMCA ji tak hrálo především samo mezi sebou.

\section{Házená}

Kromě výše uvedených sportů byla v banskobystrické YMCA, i když ne př́liš dlouho, populární házená. V roce 1924 bylo toto sdružení přijato za člena Svazu házené a ženských sportů. ${ }^{64}$

Tento rok také rychle rostla úroveň házené v tělovýchovném odboru YMCA Banská Bystrica. Trenér zde totiž nasadil velice tvrdé tréninkové podmínky, ze kterých svým svěřenkyním nic neodpustil. Po tréninku musely navíc běhat kolem hřiště a hrát volejbal. Jeho svěřenkyně mu samozřejmě často uštědřily vyčítavé pohledy, které občas vystřídalo nějaké to ostřejší slovo. Nicméně se brzy dostavily úspěchy.

Hned v prvním zápase, který byl až na dvě zkušené hráčky debutem celého týmu, dokázaly házenkářky YMCA i díky náročné př́pravě porazit mnohem starší a zkušenější tým Rudou Hviezdu Vrútky, a to navíc výrazným rozdílem $14: 1$. Převaha YMCA trvala po většinu hry a Vrútky mohly jen děkovat brankářce, která podala skvělý výkon, kterým zachránila svůj tým od mnohem výraznější prohry.

Z YMCA exceloval útok Machová - Ela Zikmundová - Zdeňka Zikmundová, který byl velice dobře sehrán. Tým YMCA předvedl skvělý útok i obranu. Pouze brankářka nebyla až tak vyzkoušena. Přesto předvedla značný klid, jistotu a také výběhy zakončené dlouhými a přesnými přihrávkami vlastnímu útoku. Kromě již jmenovaných hráček byly součástí týmu házenkářky Štekláčková, Zelenková, Hamadová a Šteffelová ${ }^{65}$

V následujících letech se však bohužel zmínky o házené v banskobystrické YMCA přestaly objevovat. Je tudíž možné, že došlo k výraznému omezení házené v tomto místním sdružení.

\section{Tenis}

Ve dnech 28. a 29. července 1925 byl na nově zřízených kurtech místního sdružení YMCA v Banské

${ }^{59}$ Almanach sportu a tělesné výchovy na rok 1931, roč. 1931, s. 161.

${ }^{60}$ Chorvát, T. (2005) Banská Bystrica a šport v rokoch 1918-1938 (vplyv športu a športových spolkov na mesto a spoločnost' Banskej Bystrice v obdobi I. Československej republiky). Banská Bystrica: Hanuman, s. $26-30$.

${ }^{61}$ Almanach sportu a tělesné výchovy na rok 1934, roč. 1934, s. 143.

${ }^{62}$ Někdy lze tento sport nalézt $\mathrm{v}$ literatuře pod názvem playground-ball. V obou př́padech se jedná o dnešní sportovní hru softbal.

${ }^{63}$ Pramen bohužel neuvádí, ve kterých letech se podařilo hráčům banskobystrické YMCA tyto tituly vybojovat.

Chorvát, T. (2005). Banská Bystrica a šport v rokoch 1918-1938 (vplyv športu a športových spolkov na mesto a spoločnost' Banskej Bystrice v obdobi I. Československej republiky). Banská Bystrica: Hanuman, s. $27-28$.

${ }^{64}$ Sport, IV., 1924, č. 22.

${ }^{65}$ Sport, IV., 1924, č. 24. 
Bystrici odehrán první místní tenisový turnaj, ve kterém proti sobě nastoupili členové YMCA a Svazu československých důstojníků. Turnaje se zúčastnilo celkem třicet tenistů. ${ }^{66}$

YMCA měla v zápasech nevýhodu v tom, že její tým tvořili téměř výhradně tenisoví začátečníci, kteří stáli proti sehranému a vyspělému důstojnickému týmu. Přesto si počínali poměrně dobře.

Z YMCA vykali především E. Zikmundová a Z. Klímo. V mužském singlu porazil V. Klímo Stubnya a Z. Klímo si poradil s Nebeským. Své utkání naopak prohrál Seidner, který nestačil na skvěle hrajícího Hňoupka. Zikmund pak nestačil na Zechetnera, Peřina na Šeböka a Huoyec na Schöna.

Ve dvouhře žen porazila Zikmundová Wagnerovou ve dvou setech $6: 0$ a $6: 0$.

Ve čtyřhře mužů podlehli členové YMCA Seidner a Zikmund dvojici Hňoupek - Zechetner. Naopak dvojice V. Klímo - Peřina si poradila s dvojicí Subnya - Šebök. Výhru pro YMCA vybojovala i dvojice Z. Klímo - Huoyec, která porazila dvojici Schön - Nebeský.

Poslední na programu byla utkání ve smíšených čtyřhrách. Dvojice Zikmund - Klímová nestačila na pár Zechetner - Vojtěchová. Z. Klímo a Rainhartová zvítězili nad dvojicí Stubnya - Seböková. V posledním zápas se utkaly dvojice Peřina - Tománková a Šebök - Kňưrová. Utkání skončilo vítězstvím druhé jmenované dvojice. YMCA ovládla celé utkání v poměru $9: 8 .{ }^{67}$

Členstvo YMCA se však př́liš tomuto sportu nevěnovalo. Tenis tak byl v banskobystrické YMCA pěstován především jako rekreační sport.

\section{Stolní tenis}

Mnohem populárnějším sportem byl mezi členy banskobystrické YMCA stolní tenis. K jeho výraznějšímu rozšíření však došlo až koncem 20 . let.

Ping-pongový odbor místního sdružení YMCA v Banské Bystrici, který se v tomto období stal prakticky centrem místního stolního tenisu, uspořádal ve dnech 9. a 10. března 1929 městský turnaj, který uskutečnil $\mathrm{v}$ jeho ping-pongové místnosti. O jeho hladký průběh se postaral sekretář YMCA Fikejz. Po skončení celé akce zamýšlel ping-pongový odbor YMCA vyslat mistry Banské Bystrice - Pavla Dobrotu a dvojici Pavla Meislingera a Eugena Riečanskiho na mezinárodní turnaj, který se konal v Piešt'anských Kúpel'och. ${ }^{6}$

Organizátoři z YMCA se rovněž snažili o to, aby místní obecenstvo mohlo na turnajích pořádaných sdružením YMCA vidět co možná nejlepší světové hráče. Na jejích turnajích se tak postupem času představilo několik mistrů světa. ${ }^{69}$

S blížícím se jarem 1933 bylo v Žilině uspořádáno II. místní ping-pongové mistrovství. Pořadatelé od počátku doufali, že se jim podaří zajistit i účast slovenské špičky. To se nakonec také podařilo, a to i přesto, že o mistra Žiliny se mohli samozřejmě ucházet pouze místní hráčky a hráči. Na turnaji se tak sešla téměř celá slovenská špička. Mistrovství probíhalo ve znamení vyrovnaných týmů, a tudíž i napínavých zápasů.

V celkovém pořadí mužů se na druhém místě umístil člen YMCA Banská Bystrica Gescheidt. Čtvrté místo pak vybojoval jeho týmový kolega Engelmann. Taktéž stolní tenistky z YMCA o sobě daly vědět. Schlesingerová vybojovala druhé a Szántová třetí místo. Mužskou dvouhru pak ovládla banskobystrická dvojice Engelmann - Fillo. ${ }^{70}$

V roce 1934 se stolní tenisté YMCA Banská Bystrica účastnili v Bratislavě mistrovství Slovenska,

${ }^{66}$ U některých hráčů nebylo z výsledkové listiny jasné, do kterého z těchto dvou týmů patřili, či zda to nebyli hráči bez členství v těchto sdruženích. Proto jsou zde uvedeni pouze hráči, jejichž členství je nepochybné.

${ }^{67}$ Tenisté reprezentující banskobystrickou YMCA jsou vždy uváděni jako první.

Sport, V., 1925, č. 31 .

${ }^{68}$ Zda se tito hráči uvedeného mezinárodního turnaje zúčastnili, se bohužel nepodařilo dohledat.

STAR, roč. 1929, č. 14.

${ }^{69}$ Chorvát, T. (2005). Banská Bystrica a šport v rokoch 1918-1938 (vplyv športu a športových spolkov na mesto a spoločnost' Banskej Bystrice v obdobi I. Československej republiky). Banská Bystrica: Hanuman, s. 29.

${ }^{70}$ STAR, roč. 1933, č. 12. 
na kterém ve finále podlehli bratislavskému I. ČsŠK (Československý športový klub). O rok později byli ve finále poraženi týmem PTE (Polgár torna egyesület - Občanský tělocvičný spolek) Bratislava. ${ }^{71}$

V banskobystrické YMCA však začala ve druhé polovině 30. let upadat tělovýchovná a sportovní činnost obecně. ${ }^{72}$ Její sportovci nedosahovali takových výsledků, či se dokonce turnajů přestávali účastnit.

\section{Zimní sezona}

V zimní sezoně byla tělovýchovná činnost YMCA samozřejmě poměrně značně omezena. Sportovci se věnovali lyžování a sáňkování. ${ }^{73}$

YMCA Banská Bystrica za vedení V. Velkoborského a pana Odvárky ustanovila v roce 1924 poměrně silný odbor lyžařu..$^{74}$ Ti se v meziválečném období účastnili řady lyžařských závodů. Sami jich také několik usporádali. ${ }^{75}$ Tento lyžařský odbor byl mj. v novinách zakotvený následujícím způsobem:

„Ač počtom malý, môže sa svojími výkonmi postavit’ medzi prvé kluby združené v Slovenskej lyžiarskej župe, s najlepšimi pretekármi Daňom, Sobotom, Fillom a Gregorom. "76

Rozsáhlejší a podrobnější zprávy však o sobě lyžaři banskobystrické YMCA bohužel nezanechali.

\section{Závěr}

Místní sdružení YMCA v Banské Bystrici patřilo od počátku své existence k jednomu z hlavních piliřru této mezinárodní organizace na Slovensku. Stejně jako v mnoha dalších československých městech i zde zpočátku YMCA spolupracovala s armádou a starala se o vojenský domov.

Po rozvázání spolupráce s armádou se začala YMCA v Banské Bystrici orientovat na práci pro civilní obyvatelstvo, která byla především tělovýchovného typu. Brzy zde došlo k vystavení sportovního hřiště, které se pak stalo základem pro rozvoj tělesné výchovy a sportu mezi členy banskobystrické YMCA.

Nejpopulárnějším sportem byla mezi členstvem lehká atletika, ve které v průběhu meziválečného období banskobystrická YMCA na středním Slovensku výkonnostně dominovala. Řadu lehkoatletických soutěží také pořádala, čímž se zasloužila o zpopularizování tohoto sportovního odvětví na Slovensku.

Stejně jako v mnoha dalších místních sdruženích se i zde ujaly sportovní hry. Ve volejbalu dokonce patřilo místní sdružení dlouho mezi nejlepší slovenské týmy. Zanedbatelné však nejsou ani jeho výsledky v basketbalu, playgroundballu či stolním tenisu. Kromě výše uvedených sportů se členstvo banskobystrické YMCA věnovalo celé řadě dalších sportovních odvětví.

S blížící se druhou světovou válkou začala banskobystrická YMCA omezovat svou činnost. Zároveň docházelo i k významné redukci počtu členů, který roku 1939 klesl na necelých 120. Oproti roku 1934, kdy jich zde bylo více jak 520, se tak jednalo o pokles velice citelný. ${ }^{77}$

Slovenská YMCA se v období od vyhlášení autonomie Slovenské republiky v ř́ijnu 1938 do vy-

${ }^{71}$ Almanach sportu a tělesné výchovy na rok 1936, roč. 1936, s. 120.

${ }^{72}$ Kromě výše uvedených sportů pěstovalo členstvo místního sdružení v Banské Bystrici v meziválečném období také cyklistiku a šerm. Kromě toho zde byly organizovány turistické výlety.

${ }^{73}$ YMCA (Časopis sdružení YMCA v Československu), II., 1924, č. 2, s. 71.

${ }^{74}$ YMCA (Časopis sdružení YMCA v Československu), II., 1924, č. 5-6, s. 186-187.

${ }^{75}$ STAR, roč. 1929, č. 2.

${ }^{76}$ Chorvát, T. (2005). Banská Bystrica a šport v rokoch 1918-1938 (vplyv športu a športových spolkov na mesto a spoločnost' Banskej Bystrice v obdobi I. Československej republiky). Banská Bystrica: Hanuman, s. 29.

${ }^{77}$ V roce 1930 vykazovala Banská Bystrica zhruba 11 tisíc obyvatel. O deset let později to pak bylo o cca dva tisíce více. 
hlášení samostatnosti Slovenska v březnu 1939 stala součástí konfederace autonomních částí - ČeskoSlovenské YMCA. ${ }^{78}$

V červnu 1940 již fungovala jako samostatná organizace v suverénní Slovenské republice, kde vydala své vlastní stanovy, ve kterých přijala název „ÚSAK (Ústredie pre sociálnu a kultúrnu starostlivost') v Slovenskej republike“ se sídlem v Bratislavě. ${ }^{79}$ Důvodem, který vedl ke změně názvu, bylo, že v roce 1939 byla organizace YMCA na Slovensku zakázána. Ke zrušení organizace YMCA v českých zemích došlo o čtyři roky později.

Po skončení druhé světové války byla činnost organizace YMCA v Československu obnovena. Dne 2. listopadu 1946 zaregistrovalo tehdejší Ministerstvo vnitra nové stanovy slovenské YMCA, jejíž původní majetek jí byl převeden z rukou ÚSAK zpět.$^{80}$ Obnovená československá YMCA tak nebyla totožná s předválečnou, nebot' na Slovensku nesla nově název „YMCA na Slovensku“.

\section{Prameny a literatura}

\section{Archivy}

Archiv hlavního města Prahy. Odbor vnitřních věcí. Spolkový katastr, sign. II/511. Československá YMCA. Karton 68.

Archiv YMCA v Bratislavě.

Archiv YMCA v České republice.

Národní archiv. Fond YMCA. Kartony 1-7.

Slovenský národný archív. Fond Policajného riaditel'stva.

Slovenský národný archív. Fond Ministerstva vnútra.

Vojenský historický archiv. Fond Ministerstvo národní obrany - presidium. roč. 1918-1923. Karton 28. č.j. 3866.

\section{Periodika}

Almanach sportu a tělesné výchovy, roč. 1923 - 1940.

Nová tělesná výchova (List pro tělesnou výchovu, tělocvik, sport, hry, skauting a pro vědecké studium těchto oborů), roč. I. (1927/1928) - XI. (1938).

Protein, roč. VIII. (2006) - XI. (2009).

Sport, roč. VII. (1927) - IX. (1929).

STAR, roč. $1926-1938$.

Táborový zpravodaj YMCA, roč. II. (1925) - IV. (1927).

YMCA (Časopis sdružení YMCA v Československu), roč. I. (1923) - IV. (1926).

\section{Literatura}

Bosák, E. et al (1969). Stručný přehled vývoje sportovních odvětví v Československu. Díl 1. Praha: Olympia.

Bureš, P., \& Plichta, J. (1931). Sport a tělesná kultura v Čsl. republice a cizině. Praha: Almanach sportu.

Chorvát, T. (2005). Banská Bystrica a šport v rokoch 1918-1938 (vplyv športu a športových spolkov na mesto a spoločnost’ Banskej Bystrice v období l. Československej republiky). Banská Bystrica: Hanuman.

Johnson, E. L. (1979). The History of YMCA Physical Education. Chicago: Association Press.

Konečný, J. (1930). YMCA: její vznik, dějiny a význam. Praha: Československá akciová tiskárna.

Machotka, J., \& Heller, A. (1920). Americké hry. Praha: Svaz Dělnických tělocvičných jednot.

Perútka, J. (1980). Dejiny telesnej výchovy a športu na Slovensku. Bratislava: Šport.

Perútka, J. et al. (1982). Malá encyklopédia telesnej výchovy a športu. Bratislava: Šport.

Perútka J. et al. (1967). Športy na Slovensku v rokoch 1945-1965. Bratislava: Šport.

Sedliačik, I. (2004). Od začiatku po začiatok (Činnost' YMCA Banská Bystrica v rokoch 1919-1999). Banská Bystrica: YMCA.

Šarochová, K. (2013) YMCA a Vysokoškolský sport jako průkopníci volejbalu v Českých zemích. (Diplomová práce). Praha: Univerzita Karlova v Praze.

Sedliačik, I. (2004). Od začiatku po začiatok (Činnost' YMCA Banská Bystrica v rokoch 1919-1999). Banská Bystrica: YMCA, s. 6.

${ }^{78}$ Národní archiv, fond YMCA, č. kartonu 1, sign. 1. Návrhy na reorganizaci YMCA v Česko-Slovensku.

79 Národní archiv, fond YMCA, č. kartonu 1, sign. 1. Stanovy slovenské organizace YMCA.

${ }^{80}$ Sedliačik, I. (2004). Od začiatku po začiatok (Činnost' YMCA Banská Bystrica v rokoch 1919-1999).

Banská Bystrica: YMCA, s. 6-8. 
The Y.M.C.A. Games (Official Report of the First International Y.M.C.A. Athletic Championships: Copenhagen, Denmark, July 10-17, 1927). (1927). Ženeva: World's Alliance of Young Men's Christian Associations.

Tlustý, T., \& Štumbauer, J. (2012). Tělesná výchova a sport v organizacích YMCA a YWCA v meziválečném Československu. České Budějovice: Jihočeská univerzita v Českých Budějovicích.

YMCA v prvním desetiletí 1921-1931. (1931). Praha: Vydavatelské oddělení YMCA.

Zatloukal, J. (1947). Památník československé tělesné výchovy a sportu. Bratislava: Nakladatelství Josef Zatloukal. 